\title{
Investigations of Milk Quality from Teats with Milk Flow Disorders
}

\author{
J. Querengässer*, T. Geishausert, K. Querengässer*, \\ K. Fehlings $\ddagger$ and R. Bruckmaier§ \\ Veterinary Clinic Babenhausen, Germany*, Department of Population Medicine, \\ University of Guelph, Canada†, Bavarian Animal Health Service, Grub, Germanył, \\ Institute of Physiology, Milk and Food Research Center Weihenstephan, Technical University Munich, Germany§
}

\begin{abstract}
The objective of this study was to investigate the quality of milk from teats with milk flow disorders. Somatic cell count, pathogens, and signs of mastitis ( $>100,000$ cells $/ \mathrm{ml}$ and pathogens detected) were determined in the milk from all teats of the udder before treatment of the affected teat, as well as 1 and 6 mo later. Teats with milk flow disorders were compared to all of the other teats from the same udder. Before treatment, the SCC from affected teats was 4.3 million higher, the odds of detecting pathogens 6 times higher, and the odds of mastitis 11 times higher than in control teats (when adjusted for other significant explanatory variables). SCC and the risk of mastitis decreased after surgical treatment of the affected teats, whereas the chance of detecting pathogens was not affected. Six months after treatment, the SCC was 1.3 million higher, and the odds of mastitis 6.5 times higher than in control teats. Throughout the study period neither SCC, the odds of detecting pathogens, nor mastitis changed significantly in control teats. It may be concluded from this study that milk quality from teats with milk flow disorders is decreased before treatment and does not reach the milk quality from unaffected teats within 6 mo after treatment.
\end{abstract}

(Key words: milk flow disorder, somatic cell count, pathogen, mastitis)

Abbreviation key: $\mathbf{C I}$ = confidence interval

\section{INTRODUCTION}

Milk flow disorders are often associated with decreased milk quality. In milk from teats with milk flow disorders the average SCC was $2.5 \mathrm{million} / \mathrm{ml}$, and pathogens were detected in 59\% of the cases when presented to veterinarians (Querengässer et al., 2001). Despite treatment of the affected teat, composite SCC was

Received September 18, 2001.

Accepted March 23, 2002.

Corresponding author: Thomas Geishauser; e-mail: tgeishau@ uoguelph.ca. on average 128,000 higher throughout lactation in affected cows than in unaffected cows (Querengässer et al., 1999). Milk flow disorders increased the risk of subclinical and clinical mastitis (Tschäppät et al., 1976; Witzig et al., 1984, Wigger and Martig, 1985; Agger and Willeberg, 1986; Zähner, 1989; Bigras-Poulin et al., 1990; Querengässer et al., 1999; Kiossis et al., 2002).

The objective of this study was to investigate SCC, the chance of detecting pathogens, and signs of mastitis in the milk from all quarters in cows with milk flow disorders both before and after treatment. We hypothesized that SCC and the odds of detecting pathogens or signs of mastitis are higher in milk from teats with milk flow disorders than in the remaining teats before treatment (first research hypothesis). We further hypothesized that milk quality from teats with milk flow disorders is equal to that of unaffeced teats 6 mo after treatment (second research hypothesis).

\section{MATERIALS AND METHODS}

\section{Animals}

This study was performed on 97 dairy cows that farmers had brought to the Veterinary Clinic Babenhausen in Bavaria between May 18, 1999, and February 1, 2000 , because they had problems milking one or two of the teats. The outer skin of the affected teat was mainly intact. A total of 100 hard milking teats were investigated. In 94 cows, only one teat was affected; three cows had two affected teats. Three cows had one blind quarter. The cows belonged to various breeds (Table 1) and originated from 78 herds. One cow was enrolled from each of 65 herds, 2 cows from 5 herds, and 3 or more from 5 herds.

\section{Procedures}

On referral, case history (Table 1) was determined, and a clinical examination (Table 2) performed. Before examination of the teat, cows received xylazine $(0.2 \mathrm{ml}$ of a $2 \%$ solution per $100 \mathrm{~kg}$ of body mass) and oxytocine (20 IU) intravenously. All udder examinations were performed at the quarter level. After cleaning the teats, 
Table 1. Case history.

\begin{tabular}{lrl}
\hline Parameter & $\%$ & Median \\
\hline Brown Swiss (Braunvieh) & 66 & \\
Simmental (Fleckvieh) & 19 & \\
Holstein (Schwarzbunte) & 11 & \\
Others & 4 & \\
Tie stall & 66 & 38 \\
Free stall & 33 & \\
Herd size (lactating cows) & & \\
Age (lactations) & 45 & \\
1 & 30 & \\
2 & 10 & \\
3 & 7 & \\
4 & 4 & \\
5 & 2 & \\
6 & 1 & \\
7 & 1 & \\
8 & & \\
DIM when presented & & \\
Duration of illness (days) & 79 & \\
Pretreated & & \\
Location of the affected teat & 12 & \\
Front left & 17 & \\
Front right & 42 & \\
Hind left & 29 & \\
Hind right &
\end{tabular}

hand milkability was assessed (milkable by hand/not milkable by hand). The teat tip to floor distance, and the teat length were measured; the teat tip thickness was determined using spring-loaded calipers (Hauptner, Solingen/Germany) (Hamann et al., 1996). After disinfection, milk samples were taken to determine SCC (1000 cells $/ \mathrm{ml}$ ), and to culture pathogens (type) (Deutsche Veterinärmedizinische Gesellschaft e.V., 2000). The pathogens were grouped into major, minor, and uncommon pathogens (Radostits et al., 2000). Mastitis was defined as an SCC greater than 100,000 with pathogens present (Deutsche Veterinärmedizinische Gesellschaft e.V., 1994); when no flakes were visible, the mastitis was defined as subclinical and when flakes were visible the mastitis was defined as clinical. Teat canal width was measured with a plug gauge (Johannson, 1957); the gauge used measured diameters from 1 to $5 \mathrm{~mm}$ in $0.5-\mathrm{mm}$ steps. Teat canal length was determined with a thelometer (Querengässer and Geishauser, 1999) (Thelometer; Eickemeyer, Tuttlingen, Germany). Cows were milked with a quarter milking machine equipped with four lactocorders (Foss, Hilleröd, Denmark) (Wellnitz et al., 1999). The lactocorders measured peak milk flow, average milk flow, and milk yield. Upon initial examination, the affected teat was only milked for $1 \mathrm{~min}$, to prevent further injury to the teat. The remaining milk was drained with a milking tube and weighed. All unaffected quarters were milked out by machine.
To diagnose the cause of the milk flow disorder, all affected teats were examined by a veterinarian using teat endoscopy (Theloscope; Eickemeyer, Tuttlingen, Germany) (Medl and Querengässer, 1994; Querengässer, 1998). With the endoscopic findings, the teats were classified into three groups as follows: 1) Rupture in the teat canal area without dislocation of tissue, 2) Rupture in the teat canal area with dislocation of tissue (inversion or eversion), and 3) Other (Querengässer et al. 2001). All milk flow disorders were surgically treated by the removal of dislocated tissue, dilation of narrowed teat canals, or extraction of free bodies from the teat cistern (Geishauser and Querengässer, 2001). After surgery, an antibiotic (600 mg of cefazolin; Merial, Halbergmoos, Germany) was administered into the teat cistern, either a silicone implant (SIMPL; profs-products.com, Germany) or a natural teat insert (NIT; profsproducts.com, Germany) was inserted into the teat canal, and the teat was bandaged and rested (not milked) for several days. Cows were reexamined 1 and 6 mo later in the herd of origin.

\section{Statistics}

The data were described as medians for continuous variables and as frequencies for categorical variables (descriptive statistics; Kreienbrock and Schach, 2000). Affected teats were compared to unaffected (control) teats. Attempts were then made to draw conclusions from the data (inductive statistics). Linear regression was used (Myers, 1990) to assess the effect of milk flow disorder (present/not present), and the effect of time relative to treatment $(0=$ before treatment, $1=1 \mathrm{mo}$ later, $6=6$ mo later) on SCC. Logistic regression (Hosmer and Lemeshow 1989) was used to assess the effect on the odds of detecting pathogens or signs of mastitis. Because an interaction between the milk flow disorder and the square root of the months after treatment was assumed in the risk of detecting pathogens, an interaction term of milk flow disorder and the square root of the months after treatment was put into the pathogen model. Because a simple interaction between milk flow disorder and months after treatment was assumed in the mastitis risk, an interaction term of milk flow disorder and the months after treatment was put into the mastitis model. Other explanatory variables, known from the literature to affect the dependent variables, were included in the model and selected by a stepwise forward procedure. Effects of the individual cow were adjusted for by using generalized estimation equations (Liang and Zeger, 1986). Odds ratios and confidence intervals were calculated from variable estimates and standard errors (Hosmer and Lemeshow, 
Table 2. Findings in teats affected and unaffected with milk flow disorders before, 1, and 6 mo after treatment.

\begin{tabular}{|c|c|c|c|c|c|c|c|c|c|c|c|c|}
\hline \multirow[b]{3}{*}{ Parameter } & \multicolumn{4}{|c|}{$\begin{array}{c}\text { Examination } \\
\text { before treatment }\end{array}$} & \multicolumn{4}{|c|}{$\begin{array}{l}\text { Reexamination } \\
1 \text { mo later }\end{array}$} & \multicolumn{4}{|c|}{$\begin{array}{l}\text { Reexamination } \\
6 \text { mo later }\end{array}$} \\
\hline & \multicolumn{2}{|c|}{$\begin{array}{c}\text { Affected } \\
\text { quarter } \\
(\mathrm{n}=100)\end{array}$} & \multicolumn{2}{|c|}{$\begin{array}{c}\text { Unaffected } \\
\text { quarter } \\
(\mathrm{n}=297) \\
\end{array}$} & \multicolumn{2}{|c|}{$\begin{array}{c}\text { Affected } \\
\text { quarter } \\
(\mathrm{n}=98)\end{array}$} & \multicolumn{2}{|c|}{$\begin{array}{l}\text { Unaffected } \\
\text { quarter } \\
(\mathrm{n}=291) \\
\end{array}$} & \multicolumn{2}{|c|}{$\begin{array}{c}\text { Affected } \\
\text { quarter } \\
(\mathrm{n}=78)\end{array}$} & \multicolumn{2}{|c|}{$\begin{array}{l}\text { Unaffected } \\
\text { quarter } \\
(\mathrm{n}=233)\end{array}$} \\
\hline & $\%$ & Median & $\%$ & Median & $\%$ & Median & $\%$ & Median & $\%$ & Median & $\%$ & Median \\
\hline \multicolumn{13}{|l|}{ Days after initial examination (n) } \\
\hline Teat tip to floor distance $(\mathrm{cm})$ & & 46 & & 47 & & 48 & & 48 & & 47 & & 47 \\
\hline Teat length $(\mathrm{mm})$ & & 60 & & 60 & & 55 & & 60 & & 55 & & 55 \\
\hline Teat tip thickness (mm) & & 14 & & 13 & & 14 & & 13 & & 13 & & 12 \\
\hline Teat canal width $(\mathrm{mm})$ & & 2 & & 2 & & 2 & & 2 & & 2 & & 2.5 \\
\hline Teat canal length (mm) & & 10 & & 9 & & 9 & & 9 & & 10 & & 9 \\
\hline SCC $(* 1000$ cells per $\mathrm{ml})$ & & 2936 & & 131 & & 725 & & 59 & & 426 & & 61 \\
\hline Mastitis & 67 & & 14 & & 65 & & 12 & & 53 & & 15 & \\
\hline Subclinical & 85 & & 100 & & 90 & & 94 & & 93 & & 94 & \\
\hline Clinical & 15 & & 0 & & 10 & & 6 & & 7 & & 6 & \\
\hline Milkable by hand & 76 & & 100 & & 100 & & 100 & & 100 & & 100 & \\
\hline Milkable by machine & 59 & & 100 & & 95 & & 100 & & 97 & & 100 & \\
\hline Milking interval (h:min) & & $7: 30$ & & $7: 30$ & & $11: 45$ & & $11: 30$ & & $11: 00$ & & $11: 30$ \\
\hline Milked yield (kg) & & 0.11 & & 1.33 & & 1.38 & & 2.30 & & 1.66 & & 2.30 \\
\hline Drained yield (kg) & & 1.38 & & 0.00 & & 0.00 & & 0.00 & & 0.00 & & $0.0 c$ \\
\hline Total yield (milked and drained) (kg) & & 1.50 & & 1.39 & & 1.55 & & 2.30 & & 1.66 & & 2.30 \\
\hline Peak milk flow (kg/min) & & 0.14 & & 0.63 & & 0.44 & & 0.63 & & 0.49 & & 0.63 \\
\hline Average milk flow $(\mathrm{kg} / \mathrm{min})$ & & 0.11 & & 0.45 & & 0.29 & & 0.45 & & 0.34 & & 0.45 \\
\hline Milking time $(\min : \mathrm{s})^{1}$ & & $1: 00$ & & $3: 15$ & & $4: 55$ & & $5: 30$ & & $4: 45$ & & $5: 20$ \\
\hline
\end{tabular}

${ }^{1}$ Milking time: When initially examined the affected teats were milked only for one minute to save the teat.

1989). The Statistical Analysis System (SAS 1999) was used for computation. The $P$ value was set at $<0.1$.

\section{RESULTS}

\section{Descriptive Statistics}

This study was performed predominantly on young brown swiss cows, kept in tie-stall barns, and belonging to herds with a median herd size of 38 cows. Cows were at a median of $3 \mathrm{mo}$ in milk and mostly pretreated. Milk flow disorder predominantly affected hind teats (Table 1). In $96 \%$ of the affected teats, a rupture in the area of the teat canal was diagnosed ( $47 \%$ without tissue dislocation, $49 \%$ with tissue dislocation); in $4 \%$, other causes were diagnosed. There seemed to be no difference between affected and unaffected teats in teat tip to floor distance, teat length, teat thickness, teat canal length, or teat canal width. Peak milk flow, average milk flow, and milk yield were lower in affected than in unaffected teats (Table 2). On initial examination, somatic cells were found 22 times more frequently, and pathogens or signs of mastitis 5 times more frequently, in the milk of affected teats than in the milk from unaffected teats. Half a year later, somatic cells were found 7 times, pathogens 3 times, and mastitis 4 times more frequently in affected than in unaffected quarters (Table 2). Major pathogens (esculin-positive and -negative streptococci) were the most common isolate from affected teats througout the study period. In the milk from unaffected teats, the proportions of major and minor pathogens were similar during the initial examination. Half a year later, however, the percentage of major pathogens had increased in unaffected quarters and was now similar to that of affected quarters (Table 3).

\section{Inductive Statistics}

In the multivariable model, on initial examination, SCC from teats with milk flow disorders was significantly higher compared to control teats, with an average difference of 4.3 million. SCC had decreased in the milk from affected teats one month after treatment. Six months after treatment SCC was still 1.3 million higher 
Table 3. Pathogens detected in the milk from affected teats and in the milk from contralateral (cl), ipsilateral (il) or diagonal (d) teats.

\begin{tabular}{|c|c|c|c|c|c|c|c|c|c|c|c|c|}
\hline \multirow[b]{2}{*}{ Pathogen } & \multicolumn{4}{|c|}{ Before treatment } & \multicolumn{4}{|c|}{1 mo later } & \multicolumn{4}{|c|}{6 mo later } \\
\hline & $\begin{array}{l}\text { affected } \\
(\mathrm{n}=87) \\
\%\end{array}$ & $\begin{array}{c}\mathrm{cl} \\
(\mathrm{n}=19) \\
\%\end{array}$ & $\begin{array}{c}\text { il } \\
(\mathrm{n}=17) \\
\%\end{array}$ & $\begin{array}{c}\mathrm{d} \\
(\mathrm{n}=13) \\
\%\end{array}$ & $\begin{array}{l}\text { affected } \\
(\mathrm{n}=86) \\
\%\end{array}$ & $\begin{array}{c}\mathrm{cl} \\
(\mathrm{n}=29) \\
\%\end{array}$ & $\begin{array}{c}\text { il } \\
(\mathrm{n}=21) \\
\%\end{array}$ & \begin{tabular}{l}
\multicolumn{1}{c}{$d$} \\
$(\mathrm{n}=19)$ \\
$\%$
\end{tabular} & $\begin{array}{l}\text { affected } \\
(\mathrm{n}=56) \\
\%\end{array}$ & $\begin{array}{c}\mathrm{cl} \\
(\mathrm{n}=27) \\
\%\end{array}$ & $\begin{array}{l}\text { il } \\
(\mathrm{n}=17) \\
\%\end{array}$ & $\begin{array}{l}\underset{c}{d} \\
(\mathrm{n}=10) \\
\%\end{array}$ \\
\hline Streptococcus agalactiae & 1 & 0 & 0 & 0 & 1 & 0 & 0 & 0 & 9 & 15 & 12 & 0 \\
\hline Streptococcus esculin positive ${ }^{1}$ & 38 & 37 & 24 & 23 & 31 & 31 & 14 & 11 & 37 & 33 & 18 & 30 \\
\hline Streptococcus esculin negative ${ }^{2}$ & 24 & 11 & 0 & 0 & 17 & 7 & 0 & 0 & 11 & 14 & 6 & 10 \\
\hline Staphylococcus spp. ${ }^{3}$ & 16 & 37 & 52 & 54 & 16 & 42 & 48 & 63 & 14 & 26 & 23 & 20 \\
\hline Staphylococcus aureus & 10 & 10 & 24 & 15 & 13 & 14 & 28 & 11 & 16 & 4 & 23 & 20 \\
\hline Coliforms & 7 & 5 & 0 & 0 & 10 & 0 & 0 & 5 & 3 & 4 & 0 & 0 \\
\hline Arcanobacter pyogenes & 4 & 0 & 0 & 0 & 6 & 0 & 0 & 0 & 2 & 0 & 12 & 10 \\
\hline Yeasts & 0 & 0 & 0 & 0 & 1 & 0 & 5 & 0 & 0 & 0 & 0 & 0 \\
\hline Others $^{4}$ & 0 & 0 & 0 & 8 & 5 & 6 & 5 & 10 & 8 & 4 & 6 & 10 \\
\hline Major pathogens ${ }^{5}$ & 80 & 63 & 48 & 46 & 77 & 58 & 47 & 37 & 84 & 74 & 65 & 70 \\
\hline Minor pathogens ${ }^{6}$ & 16 & 37 & 52 & 54 & 16 & 42 & 48 & 63 & 14 & 26 & 23 & 20 \\
\hline Uncommon pathogens ${ }^{7}$ & 4 & 0 & 0 & 0 & 7 & 0 & 5 & 0 & 2 & 0 & 12 & 10 \\
\hline
\end{tabular}

${ }^{1}$ Str. esculin positive: Str. uberis, Enterococci (DVG, 2000).

${ }^{2}$ Str. esculin negative: Str. dysgalactiae, Str. Lancefield group C, G and L (DVG, 2000).

${ }^{3}$ Sta. spp: except Sta. aureus.

${ }^{4}$ Others: Enterobacteriaceae, Proteus, Serratia marcescens and Pseudomonads.

${ }^{5}$ Major pathogens: Str. agalactiae, Str. esculin positive, Str. esculin negative, Sta. aureus, Coliforms, others (Radostits et al., 2000).

${ }^{6}$ Minor pathogens: Sta. spp. (coagulase negative Sta.) and Corynebacterium bovis (Radostits et al., 2000).

${ }^{7}$ Uncommon pathogens: A. pyogenes and yeasts (Radostits et al., 2000). 
Table 4. Quarter somatic cell count (million cells/ml of milk) model. Explanatory variables, estimates, standard errors and $P$ values are given.

\begin{tabular}{lccc}
\hline Variable & Estimate & SE & $P$ \\
\hline Constant & -2.250 & 0.844 & 0.01 \\
Milk flow disorder present vs not present & 2.900 & 0.483 & 0.00 \\
Months after treatment & 0.021 & 0.023 & 0.37 \\
Milk flow disorder * square root of the months after treatment & -1.230 & 0.251 & 0.00 \\
Hind teats vs front teats & 0.364 & 0.364 & 0.00 \\
Teat end thickness (mm) & 0.164 & 0.058 & 0.00 \\
Teat canal width (mm) & 0.484 & 0.282 & 0.09 \\
Pathogen detected vs not detected & 1.060 & 0.209 & 0.00 \\
Simmental vs others & -0.548 & 0.174 & 0.00 \\
Milked yield (kg) & -0.263 & 0.100 & 0.01 \\
Milking time (sec) & -0.001 & 0.000 & 0.02 \\
\hline
\end{tabular}

than in unaffected teats according to that model. Quarter SCC was higher in free-stall barns than in tie-stall barns and increased with increasing teat end thickness and increasing teat canal width. Pathogens increased SCC. Somatic cell count was lower in Simmental breeds than in others and decreased with increasing milk yield and increasing milking time (Table 4, Figure 1).

Throughout the study period, the odds of detecting pathogens averaged 6 times higher (90\% CI: 4.5 to 8.2 times higher) in the milk from affected teats than in the milk from unaffected teats. The odds of detecting pathogens increased herd size, with days in milk, and with SCC increased (Table 5, Figure 2).

Mastitis was 8.2 to 20 times more likely (90\% confidence interval $[\mathbf{C I}])$ in quarters with milk flow disorders than in quarters without milkflow disorders (an average of 11 times more likely). In affected quarters the odds of mastitis decreased after treatment. Half a year

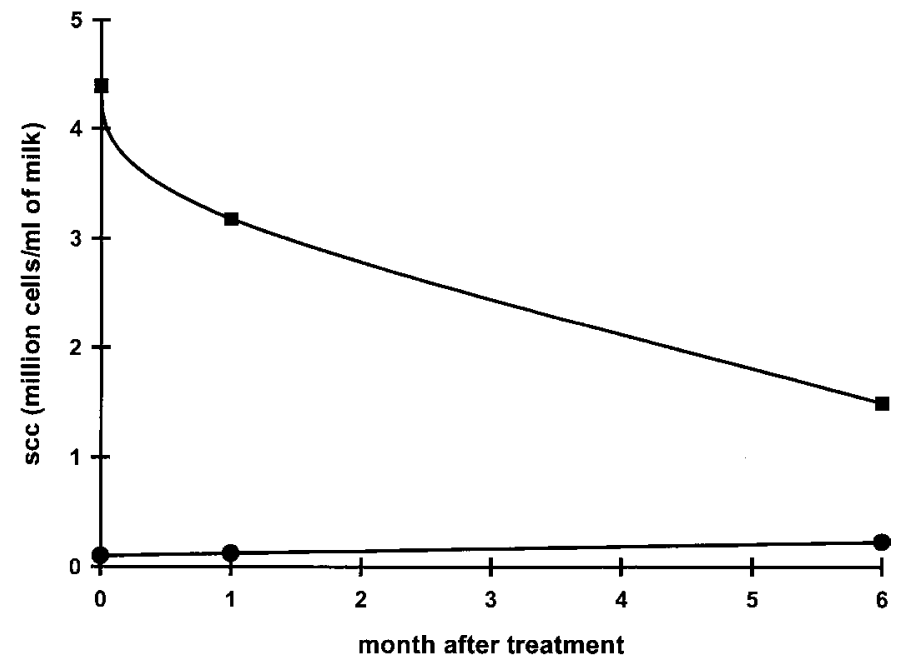

Figure 1. Somatic cell count in the milk from affected (ם) or unaffected $(\mathbf{)})$ teats before and after treatment. Calculated for the hind teats of an average simmental cow; affected teats with pathogen, unaffected teat without pathogen in the milk. after treatment, mastitis averaged 6.5 times more likely in affected quarters than in unaffected quarters $(90 \%$ CI: 1.3 to 11 times more likely). The odds of mastitis increased with herd size, DIM, and with teat canal thickness (Table 6, Figure 3).

\section{DISCUSSION}

The results confirm the first research hypothesis as before treatment, either SCC, the odds of detecting pathogens, or the odds of mastitis were higher in milk from teats with milk flow disorders than in the milk from teats without milk flow disorders. This agrees with other studies reporting high SCC and frequent presence of pathogens in milk from teats with milk flow disorders (Tschäppät et al., 1976; Querengässer et al., 2001), and an association between teat injury and mastitis (Witzig et al., 1984; Wigger and Martig, 1985; Agger and Willeberg, 1986; Zähner, 1989; Bigras-Poulin, et al., 1990).

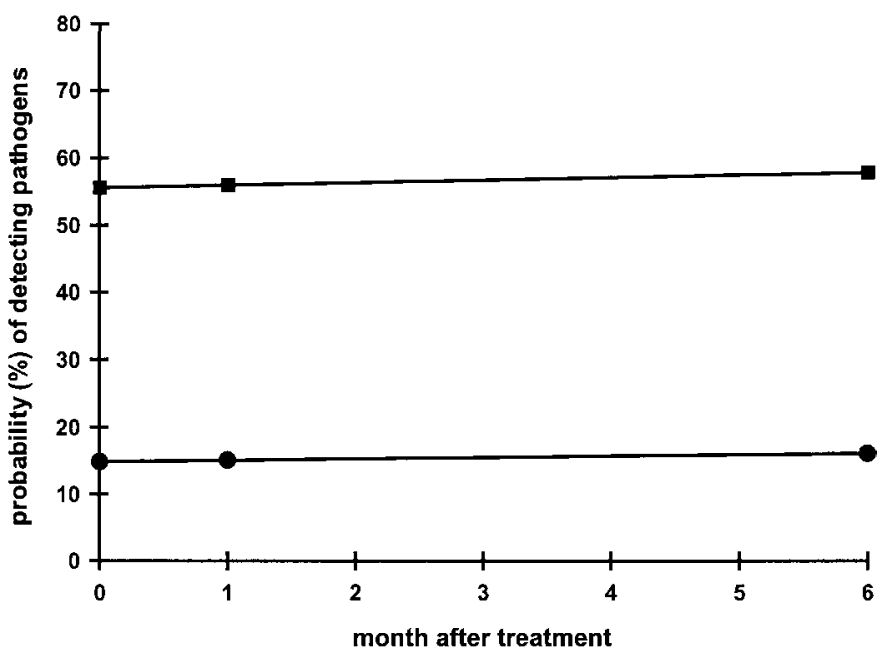

Figure 2. Probability of detecting pathogens in the milk of affected

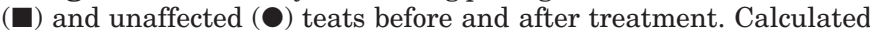
for an average cow. 
Table 5. Model of the odds (logit) of detecting pathogens in the milk from a quarter. Explanatory variables, estimates, standard errors, and $P$ values are given.

\begin{tabular}{lcll}
\hline Variable & Estimate & SE & $P$ \\
\hline Constant & -2.320 & 0.299 & 0.00 \\
Milk flow disorder present vs not present & 1.800 & 0.184 & 0.00 \\
Month after treatment (n) & 0.015 & 0.033 & 0.64 \\
Herd size (lactating cows) & 0.010 & 0.004 & 0.01 \\
DIM (n) & 0.002 & 0.001 & 0.03 \\
SCC (*1000 cells/ml) & 0.000 & 0.000 & 0.00 \\
\hline
\end{tabular}

In the present study, subclinical, not clinical mastitis was diagnosed in most quarters with milk flow disorders. Pathogens and high SCC in milk from teats with milk flow disorders may be a consequence of teat injury and of inappropriate pretreatment. Closure of the teat canal may be impaired after injury and might allow pathogens to enter the quarter, thus causing a high SCC. In a previous study, SCC averaged 1.6 million higher in cows that had been pretreated than cows that hadn't (Querengässer and Geishauser, 1999).

The second research hypothesis was rejected, however, because half a year after treatment, milk quality from affected teats was still not as good as from unaffected teats. During this period, SCC and the odds of mastitis had decreased in affected quarters, the odds of detecting pathogens, however, remained unchanged. The findings of this study are in accordance with others reporting a decline in SCC after treatment of milk flow disorders (Kiossis et al., 2002). However, earlier studies have shown that the composite SCC in cows affected with milk flow disorders is higher throughout lactation

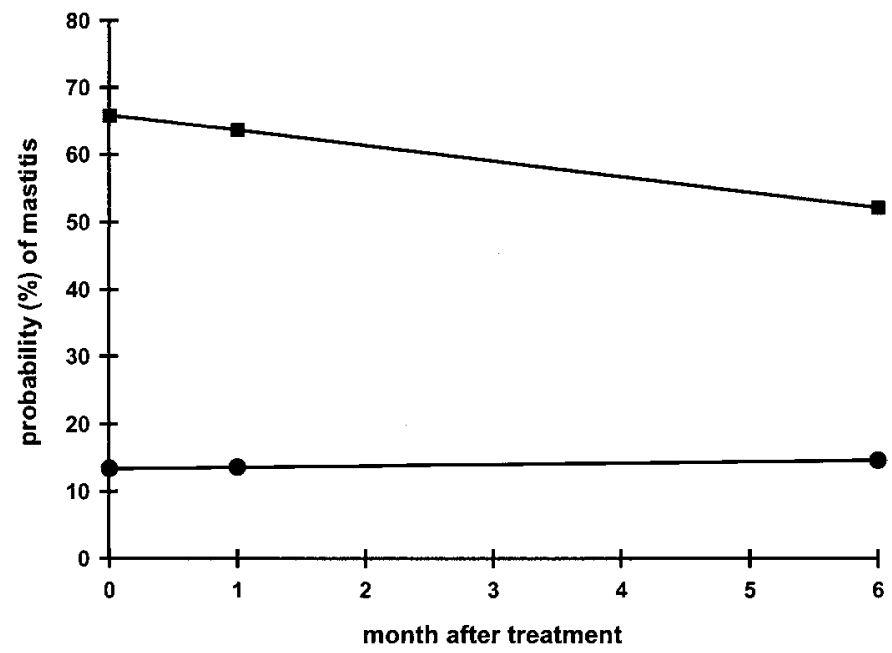

Figure 3. Probability of detecting signs of mastitis (somatic cell count $>100,000 \cup$ pathogen present) in the milk of affected $(\square)$ or unaffected (-) teats before and after treatment. Calculated for an average cow.
Table 6. Model of the odds (logit) of detecting signs of mastitis in the milk of a quarter. Explanatory variables, estimates, standard errors, and $P$ values are given.

\begin{tabular}{lrll}
\hline Variable & Estimate & SE & $P$ \\
\hline Constant & -4.000 & 0.642 & 0.00 \\
Milk flow disorder present vs not present & 2.520 & 0.233 & 0.00 \\
Months after treatment (n) & 0.017 & 0.044 & 0.71 \\
Milkflow disorder * & & & \\
Months after treatment & -0.111 & 0.059 & 0.06 \\
Herd size (lactating cows) & 0.013 & 0.005 & 0.00 \\
DIM (n) & 0.002 & 0.001 & 0.02 \\
Teat end thickness (mm) & 0.102 & 0.040 & 0.01 \\
\hline
\end{tabular}

than in unaffected cows (Querengässer et al., 1999). It may be hypothesized that the affected quarter is responsible for the increased composite SCC, as the SCC of the remaining teats was normal and did not change significantly throughout the study period. Teat injuries seem to increase the risk of quarter infection over a long period of time (Tschäppät et al., 1976; Agger and Willeberg, 1986). Further study is needed to determine if pathogens from the affected quarter can infect the unaffected quarters. Because the odds of detecting pathogens were low in unaffected quarters and did not change throughout the study period, it may be hypothesized that the risk of infection is generally low. Our results agree with others (Gedek et al., 1987), in that esculin-positive and -negative Streptococci were most frequently found in the milk from teats with milk flow disorders.

Other factors affected milk quality in this study: SCC decreased with increasing milking time (Bahr et al., 1995) and increased with increasing teat end thickness (Zecconi et al., 1996), increasing teat canal width (Jorstad et al., 1989), and pathogens detected (Querengässer and Geishauser, 1999). Swelling of the teat end, widening of the teat canal, infection with pathogens, and increase of SCC were significantly associated with the injury of the teat $(\mathrm{P}<0.001)$. The odds of detecting pathogens increased with days in milk (Jayarao et al., 1999), and the milk yield decreased with increasing SCC (Hortet and Seegers, 1999; Querengässer et al., 1999). Further evaluation is needed to discover why quarter milk yield was higher in free stall barns than in tie stall barns, and why the odds of detecting pathogens or the odds of mastitis increased with increasing herd size.

It may be concluded from this study that milk quality from teats with milk flow disorders is lower than in teats without milk flow disorders before treatment, that milk quality from affected teats may not meet the milk quality of unaffected teats within half a year after treatment, and that milk quality from unaffected teats was normal and did not change within half a year after treatment of the affected teat. 


\section{ACKNOWLEDGMENTS}

We thank Hermann Graf from the Bavarian Milk Testing Ring in Günzburg, Germany for milk cell counting, Dr. Dieter Schillinger from MERIAL in Hallbergmoos, Germany, and Dr. Wolfgang Traeder and Georg Wolter from PFIZER in Karlsruhe, Germany for financial support.

\section{REFERENCES}

Agger, J. F., and P. Willeberg. 1986. Epidemiology of teat lesions in a dairy herd. II. Associations with subclinical mastitis. Nord. Vetmed. 38:220-232.

Bahr, T., R. Preisinger, and E. Kalm. 1995. Untersuchungen zur Zellzahl und Melkbarkeit beim Rind. 2. Mitteilung: Genetische Parameter der Melkbarkeit. Züchtungskunde 67:105-116.

Bigras-Poulin, M., A. H. Meek, and S. W. Martin. 1990. Interrelationships of health problems and age on milk production from consecutive lactations in selected Ontario Holstein cows. Prev. Vet. Med. 8:15-24.

Deutsche Veterinärmedizinische Gesellschaft e.V. 1994. Leitlinien zur Bekämpfung der Mastitis des Rindes als Herdenproblem. DVG, Fachgruppe "Milchhygiene", Sachverständigenausschuss "Subklinische Mastitis", Kiel, 3. Auflage, ISBN 3-930511-03-7.

Deutsche Veterinärmedizinische Gesellschaft e.V. 2000. Leitlinien zur Entnahme von Milchproben unter antiseptischen Bedingungen und Leitlinien zur Isolierung und Identifizierung von Mastitiserregern. DVG, Fachgruppe "Milchhygiene", Sachverständigenausschuss "Subklinische Mastitis", ISBN 3-93051181-9.

Gedek, W., E. Kleinschroth, and J. Deneke. 1987. Subklinische Mastitis. Empfehlungen für die Therapie der subklinischen Mastitis des Rindes. 1. Teil. Vet 3, issue 6:6-8.

Geishauser, T., and K. Querengässer. 2001. Using teat endoscopy (theloscopy) to diagnose and treat milk flow disorders in cows. Bov. Pract. 35.2:156-164.

Hamann, J., G. A. Mein, and B. Nipp. 1996. Recommended method for measuring changes in thickness of the bovine teat with springloaded calipers. J. Dairy Res. 63:309-313.

Hosmer, D. W., and S. W. Lemeshow. 1989. Applied Logistic Regression. Verlag Wiley, New York.

Hortet, P., and H. Seegers. 1998. Calculated milk production losses associated with elevated somatic cell counts in dairy cows: review and critical discussion. Vet. Res. 129:497-510.

Jayarao, B. M., B. D. Gillespie, M. J. Lewis, H. H. Dowlen, and S. P. Oliver. 1999. Epidemiology of Streptococcus uberis intramam- mary infections in a dairy herd. Zentralbl. Vetmed. Reihe B. 46:433-442.

Johansson, I. 1957. Untersuchungen über die Variation in der Euterund Strichform der Kühe. Z. Tierz. Züchtungsbiol. 70:233-270.

Jorstad, A., T. B. Farver, and H. Riemann. 1989. Teat canal diameter and other cow factors with possible influence on somatic cell counts in cow milk. Acta. Vet. Scand. 30:239-245.

Kiossis, E., J. Riedl, B. L. Daffner, and R. Stolla 2002. Untersuchungen zur Eutergesundheit und Melkbarkeit nach endoskopisch kontrollierter Behandlung von Zitzenstenosen des Rindes. Prakt. Tierarzt 83:60-68.

Kreienbrock, L., and S. Schach. 2000. Epidemiologische Methoden, 3rd ed. Spektrum, Akad. Verl., Heidelberg, Berlin.

Liang, K. Y., and S. Zeger. 1986. Longitudinal data analysis using generalized linear models. Biometrika 73:13-22.

Medl, M., and K. Querengässer. 1994. Die Endoskopie der Zitze des Rindes. Veterinär Spiegel 3:4-11.

Myers, R. H. 1990. Classical and modern regression with applications. 2nd ed. Duxbury Press, Belmont, CA.

Querengässer, K. 1998. Diagnose und Therapie von Zitzenstenosen beim Rind mittels Endoskopie. Diss., Vet.-Med. Fak., Zürich.

Querengässer, K., and T. Geishauser. 1999. Untersuchungen zur Zitzenkanallänge bei Milchabflußstörungen. Prakt. Tierarzt. 80:796-804.

Querengässer, K., T. Geishauser, and M. Nitschke. 1999. Untersuchungen zu Milchleistung, Milchgüte und Verbleib von Kühen nach gedeckter Zitzenverletzung. Prakt. Tierarzt 80(Colleg. Veter. XXIX):52-58.

Querengässer, K., T. Geishauser, J. Querengässer, M. Nitschke, T. Melle, R. Bruckmaier, and K. Fehlings. 2001. Milchabflußstörung beim Rind-Befunde von 244 Fällen. Prakt. Tierarzt 82:816-826.

Radostits, O. M., C. C. Gay, D. C. Blood, and K. W. Hinchcliff. 2000. Pages 603-700 in Mastitis, Veterinary Medicine. 9th ed. Sanders, London.

SAS User's Guide, Version 8 Edition. 1999. SAS Inst., Inc., Cary, NC.

Tschäppät, R., H. Baumgartner, and J. P. Weisen. 1976. Der Einfluss von Zitzenoperationen auf die Eutergesundheit. Schweiz. Arch. Tierheilkrd. 118:515-523.

Wellnitz, O., R. M. Bruckmaier, and J. W. Blum. 1999. Milk ejection and milk removal of single quarters in high yielding dairy cows. Milchwissenschaft 54:303-306.

Wigger, J., and J. Martig. 1985. Verlaufsuntersuchungen nach operativer Behandlung von Zitzenverletzungen beim Rind. Dtsch. Tierärztl. Wschr. 92:247-251.

Witzig, P., P. Rüsch, and M. Berchtold. 1984. Wesen, Diagnose und Behandlung von Schleimhautabrissen im Bereich des Strichkanals. Dtsch. Tierärztl. Wschr. 91:219-222.

Zähner, M. 1989. Eutergesundheit nach Zitzenoperationen. Diss., Vet.-Med. Fak., Zürich.

Zecconi, A., V. Bronzo, R. Piccinini, P. Moroni, and G. Ruffo. 1996. Field study on the relationship between teat thickness changes and intramammary infections. J. Dairy Res. 63:361-368. 